\title{
A Comparison on the Weathering Effect in Florida, Okinawa and Awaji Island
}

\author{
Katsumi Kimura*, Sadaichi Otani* \\ and Akira Hamamoto* \\ Shinto Paint Co.
}

\begin{abstract}
A series of glossy finishes pigmented with an organic red pigment and a rutile titanium dioxide was exposed simultaneously in Florida in the United States, Okinawa and Awaji Island in Japan. The panels were examined periodically on gloss and color changes during the exposure period.

The gloss retention was the highest in Florida where the solar radiation was the greatest among these locations. The lower values in gloss retention in Okinawa and Awaji Isl. might be attributed to the heavier rainfall and longer sunshine hours in these locations.

When the color was measured without polishing the exposed panels, the color change in Okinawa was about the same degree as that in Florida, and in Awaji Isl., that was slightly less. The color changes in this measurement might be affected by both the haze on the paint surface and the fading of the red pigment in the film.

When the measurement was done after polishing the panels, the color change was the greatest in Florida. In Okinawa and Awaji Isl., these were respectively about $80 \%$ and $60 \%$ of that in Florida. These values, which might be resulted mainly from the fading of the red pigment, were nearly proportional to the amount of solar radiation in each location.
\end{abstract}

* 6-10-73, Minamitsukaguchi, Amagasaki-city, Japan

$\overline{12[8]}$ 


\title{
フロリダ, 沖繩および焱路島での暴露効果の比較
}

\author{
木村 克已* ·大谷貞一*・浜 本 朗*
}

要 旨

有機赤顔料とルチル型チタン白を使用した塗料を㙦った塗板をフロリダ，沖繩扣よば淡 路島の三地区に同時に暴露して環境と効果の関係を検討した。

三地区の中で日射量が最高であるフロリダで光沢低下が最低であった。沖繩特よび淡路 島での光沢低下が著しいのは降水量扔よび日照時間がフロリダに比して著しく大きいこと が主因であろう。

暴露した叙面をポリッシングしないで測色した場合は沖繩での変退色はフロリダでのそ れと同程度で, 淡路島ではそれより少ない。この場合の変色は塗面上の曇り之赤顔料の退 色が重なって現われた結果と考允られる。

塗面をポリッシュし，表面の曇りを除いて測色した結果では，変色度はフロリダで最高 となり，沖繩ではその約 80\%，淡路島では約 60\% の変色度であった。これらの值はこの 三地区の日射量にほぼ比例していた。

\section{1. 緒言}

塗料の屋外暴露による光沢低下, チョーキング, 変退 色，ワレ，フクレ，拉よ゙゙サビの発生などの劣化現象は 日光, 雨, 露, 湿度, 気温, 海塩粒子, 大気污染物質な ぞの気象要因によって左右される。これらの気象要因は 場所により，また季節によって異なるのはもちろんであ るが，年間の平均または合計值でも，年によって変化す るものである。天然暴露試験との相関性を検討した促進 試験法についての報告1 4) もあるが，な拈多くの問題が 残っている。一方, 暴露場所を変えて効果を比較した試 みも海外の文献 ${ }^{1,5 ~ 8)}$ に見られるが，わが国内各地間和よ び海外地との比較については報告が少ない $2,3,9,10) 。$

たとえば Freier ${ }^{8)}$ はドイッ，特よびオランダの山岳 地, 海岸および工業地带の諸地域とフロリダとの比較を 扣こなっている。また酸化チタンを含む塗膜について, $\mathrm{MuCk}^{6,7)}$ はドイッ西部とフャリダでの数年間の暴露結 果をその気象要因並びに実験室でのモデル実験の結果と 対比している。

筆者らはフロリダ, 沖繩および淡路島で同一の上塗塗 料を同時期にバクロし，光沢低下拉よび変退色を中心に

昭和 49.2 .18 受理

* 神東塗料 (株) 研究第 1 部

尼崎市南塚口町 6 丁目 10-73
バクロ効果の比較を捛こなった。

\section{2. 実験}

\section{1 供試塗料}

使用した塗料はエポキシ変性メラミンアルキド塗料の 赤色系三色で, バインダー組成はヤシ油アルキド（油長 $32 \%$ )/ブチル化メラミン/エピコート 1001=77/18/5 (固 形分比）である。三色中の一色はナフトール系アゾ顔 料，パーマネントレッド F $5 \mathrm{RK}$ (ヘキスト社）を用い た原色塗料, 他の二色はこれに耐候性ルチルチタン白, R-CR 3 (British Titan Product) を用いた白原色(PVC =15\%）を混合して調色したものである。混合比は重量 比で赤原色/白原色 $=1 / 1$ (中色), 执よび $1 / 9$ (淡色) とした。それら塗料の組成と色相を表-1 に示す。

\section{2 供試塗板の調整}

電着プライマーを塗装した $150 \times 300 \times 0.8 \mathrm{~mm}$ のダ ル鋼板上に表-1 に示した各色を 12 枚ずつェアスプレー

Table 1. PVC and color of the paints examined

\begin{tabular}{l|c|c|c|cc}
\hline Designation & $\begin{array}{c}\text { PVC of } \\
\text { red } \\
\text { pigment }\end{array}$ & $\begin{array}{c}\mathrm{PVC}^{2} \\
\text { of } \\
\mathrm{TiO}_{2}\end{array}$ & $\begin{array}{c}\text { Total } \\
\text { PVC }\end{array}$ & $\begin{array}{c}\text { Paint color } \\
\text { (Munsell } \\
\text { Value) }\end{array}$ \\
\hline Full shade & 6.0 & - & 6.0 & $7.5 \mathrm{R}$ & $3 / 12$ \\
Middle shade & 2.9 & 5.7 & 8.6 & $2.5 \mathrm{R}$ & $4 / 10$ \\
Tint shade & 0.6 & 10.9 & 11.5 & $5 \mathrm{RP}$ & $6 / 9$ \\
\hline
\end{tabular}


で塗装し， $150^{\circ} \mathrm{C}$ で 30 分焼付けて調整した。

\section{3 暴露条件}

各暴露場の位置はつぎの通りで, 暴露角度はいずれも 南面 $45^{\circ}$ とした。

淡路島: 津名郡東浦町, 北緯 $34.5^{\circ}$

(海岸加ら約 $200 \mathrm{~m}$ )

沖 繩: 那霸市内高台, 北緯 $26.3^{\circ}$ (海岸加約 $1 \mathrm{~km}$ )

フロリダ : Miami，北緯 $25.7^{\circ}$

(Salt atmosphere)

暴露はいずれも 1970 年 5 月末から開始し，一年間続行 した。供試塗板は各暴露場に各色共，4枚ずつ暴露し三 カ月ごとに 1 枚ずつ持ち帰って試験に供した。

\section{4 気象要因}

暴露期間中の気象要因については，フロリダはSouth Florida Test Service 社から毎月送られてくる測定值 を，沖繩については那霸気象台の記録を，また淡路島に ついては州本測候所の記録を利用した。ただし淡路島の 日射量に関しては神戸海上気象台の測定值を利用した。

沖繩执よび淡路島での日射量は水平面に対しての測定

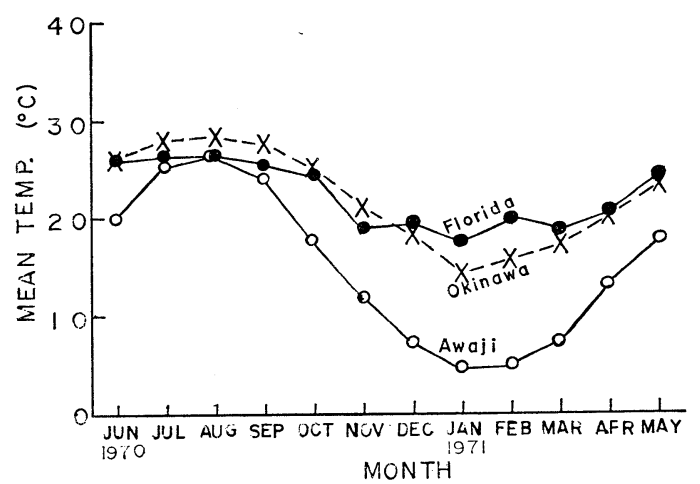

Fig. 1. Monthly mean temperature

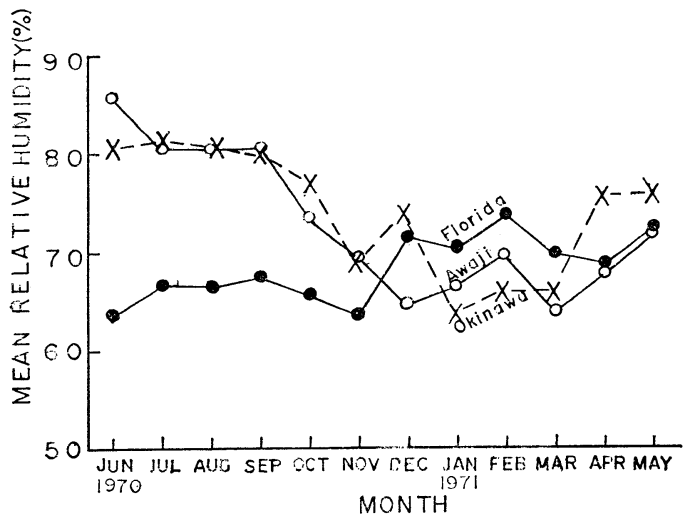

Fig. 2. Monthly mean relative humidity
值であり，フロリダでのそれは南面 $45^{\circ}$ の測定值である が，日本ウェザリングテストセンターの 1972 年に括け る銚子での測定結果 ${ }^{11)}$ とよれば年合計日射量は，水平面 で 116557 Langley，南面 30で 120642 Langley，牧よ び南面 $45^{\circ}$ で 109202 Langley となって牤り水平面と南 面 $45^{\circ}$ との差は $6 \%$ 程度であることから推定して, 概略 の比較は可能であろう。

\section{5 光沢と色差の測定}

暴露場から三カ月ごとに持ら帰った塗板はスポンジで 軽くこすりながら水洗いし，自然乾燥させた後，村上式 光沢計 (GM-3 型) で $60^{\circ}$ 鏡面光沢を測定し，一方自記 分光光度計 (日立 EPR-2 型) で分光反射率を測定し暴露 前に測定して和いたそれとから Lab 色差をコンピュー タを用いて計算した。また塗面をポリッシング剂（Sanpoly 三彩化工製）を含ませたガーゼでポリッシュし， 光沢が回復する程度に表面チョーキングを除去した場合 についても同様にして色差を測定した。

\section{3. 結果と考察}

三地点の暴露場について期間中の月平均気温，月平均

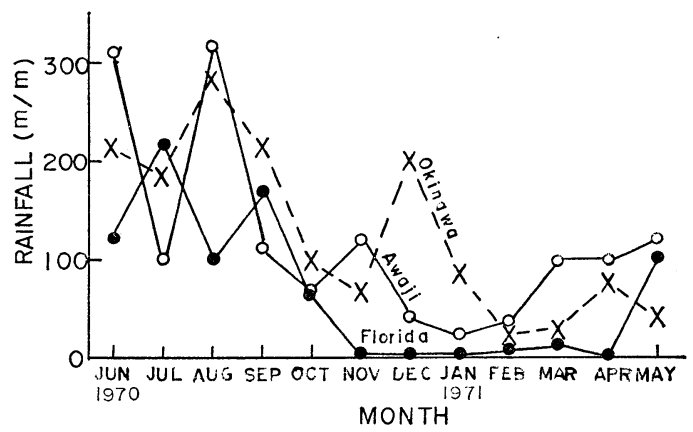

Fig. 3. Monthly rainfall

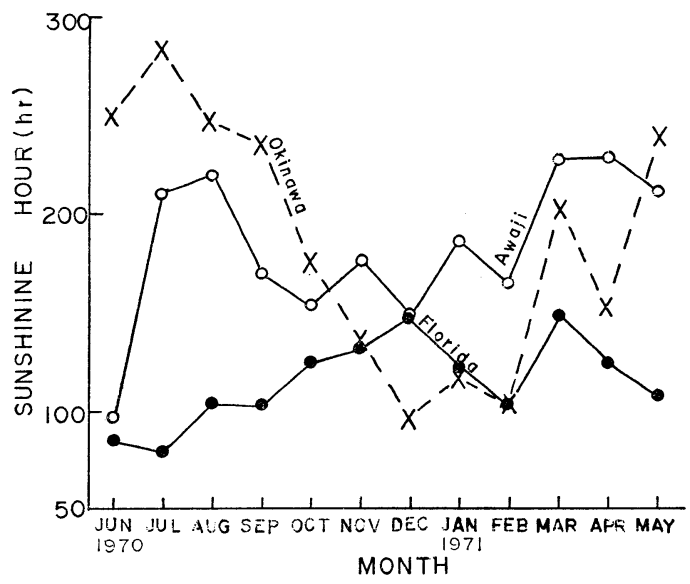

Fig. 4. Monthly sunshine hour 
湿度, 月間降水量, 月間日照時間和よび月間日射量をそ れぞれ図-1〜-5 に示した。また暴露期間を通じての平 均または合計值を表-2にまとめて示した。

暴露した三色の塗板について期間中の $60^{\circ}$ 鏡面光沢の 変化をそれぞれ図-6〜-8 に，また Lab 色差の変化を図

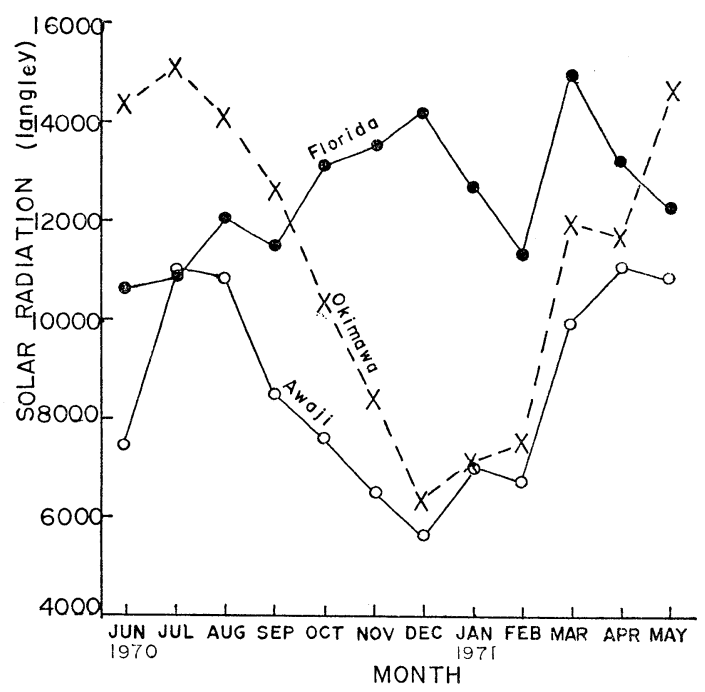

Fig. 5. Monthly solar radiation

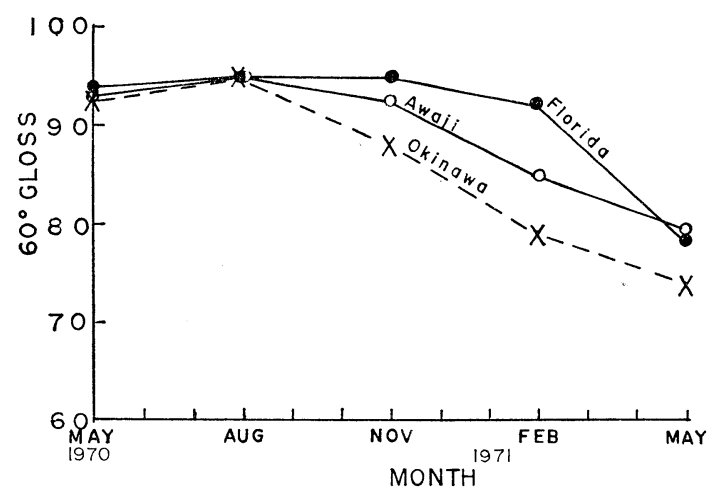

Fig. 6. Gloss of full shade

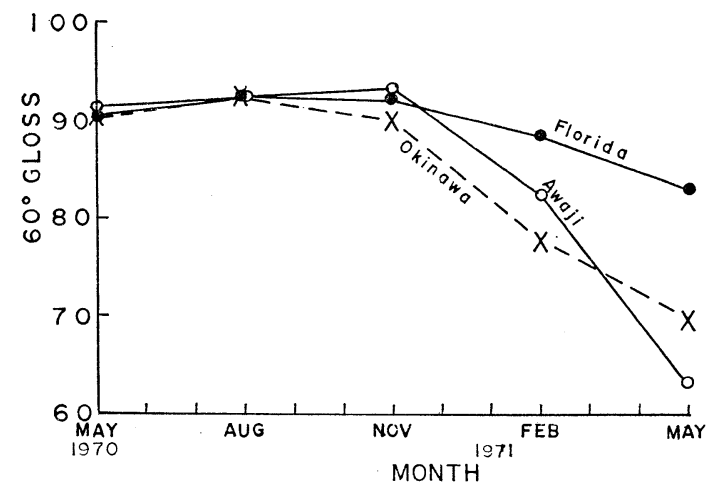

Fig. 7. Gloss of middle shade
-9〜-11に示した。図-12 特よび図-13 はそれぞれ濃色 牤よび中色について, 暴露後ポリッシングした場合の色 差を示したものである。

暴露期間中の気象要因についてみれば, 気温について はフロリダ括よび沖繩に比べ淡路島が低く，湿度拉よび 降水量は沖繩>淡路島>フロリダの順となる。年間日射 量はフロリダ>沖繩>淡路島の順となっている。

図-6〜-8 から沖繩特よび淡路島ではフトリダに比し

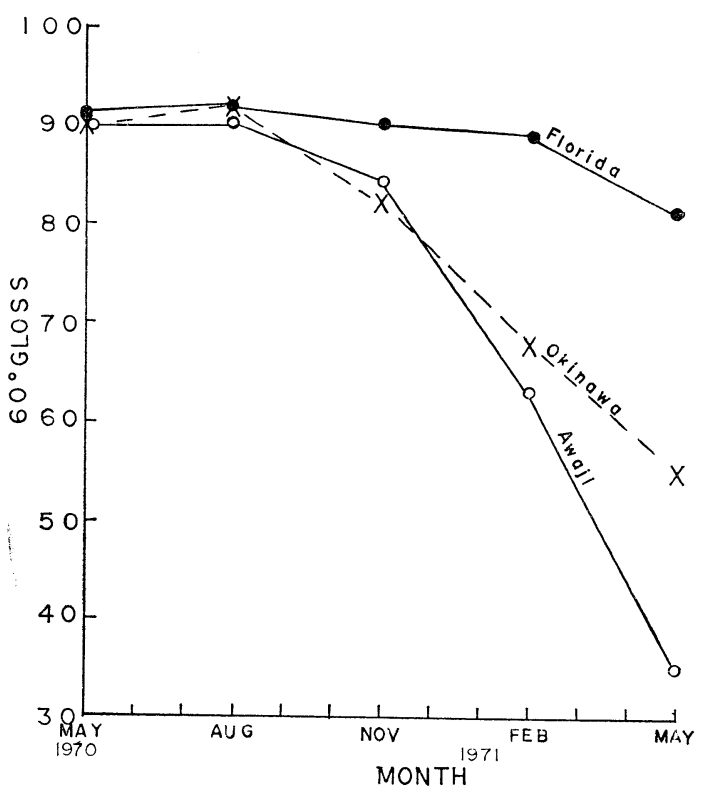

Fig. 8. Gloss of tint shade

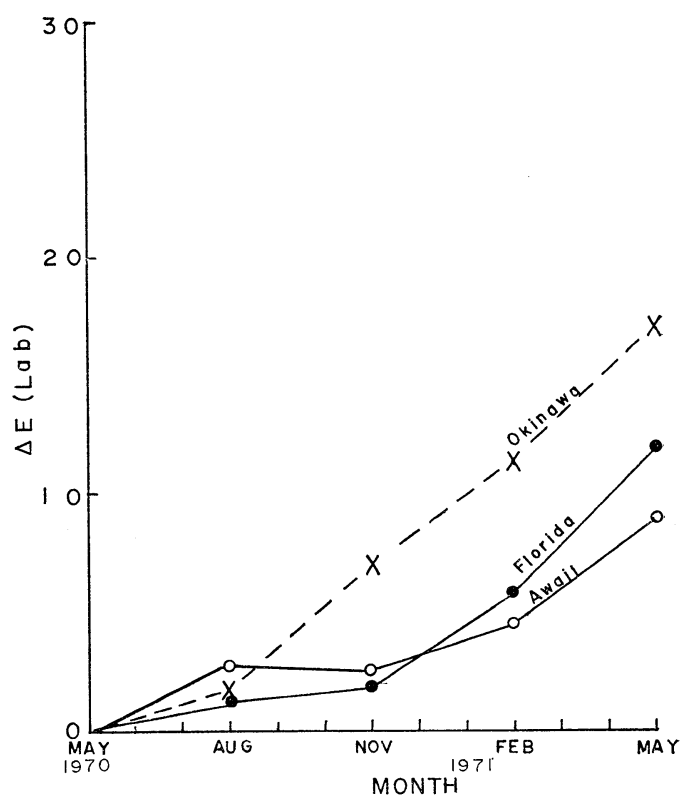

Fig. 9. Color retention of full shade 
Table 2. Climatic conditions throughout the exposure period

\begin{tabular}{l|r|r|r}
\hline Item Location & Florida & Okinawa & Awaji Isl. \\
\hline $\begin{array}{c}\left.\text { Mean temp. ( }{ }^{\circ} \mathrm{C}\right) \\
\text { Mean relative } \\
\text { humidity (\%) }\end{array}$ & 22.5 & 22.3 & 15.2 \\
$\begin{array}{c}\text { Total } \\
\text { rainfall (mm) }\end{array}$ & 809 & 1,519 & 1,457 \\
$\begin{array}{c}\text { Total } \\
\text { sunshine hours }\end{array}$ & 1,386 & 2,233 & 2,205 \\
$\begin{array}{c}\text { Total } \\
\text { solar radiation } \\
\text { (Langley) }\end{array}$ & 150,524 & 134,605 & 104,523 \\
\hline
\end{tabular}

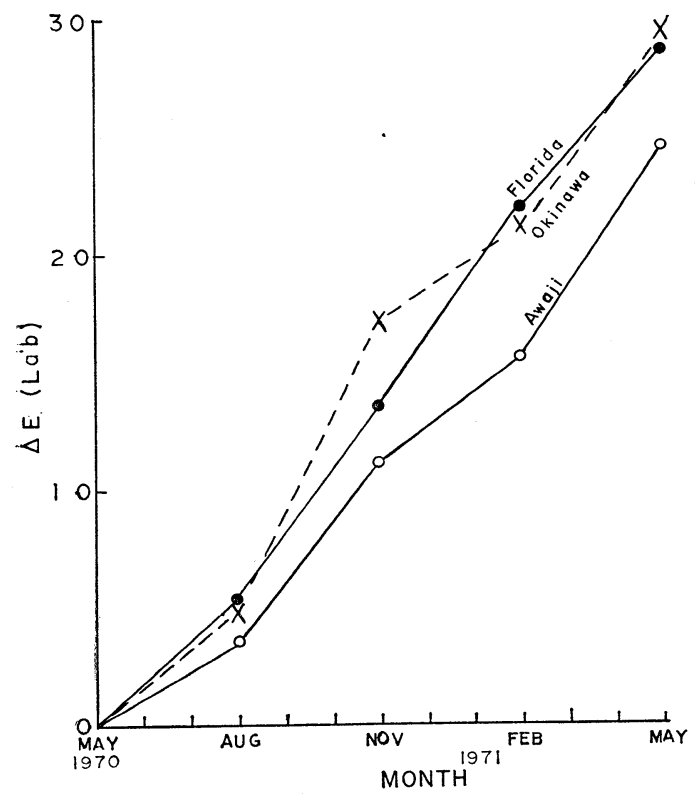

Fig. 10. Color retention of middle shade

て光沢低下が大きく，とくにチタン白含有率並びにPVC が高い淡色の場合（図-8）飞その差が大きく，一年間暴 露後の光沢残存率はフロリダでの $90 \%$ に対して沖繩で $61 \%$ ，また淡路島では $39 \%$ で，すでにチョーキングし ている。表-2 に示した気象因子で沖繩と淡路島とに汪 ぼ共通してフロリダよりも大きな值を示しているのは降 水量, 日照時間拉よび相対湿度である。一般にウェザオ メーターによる促進試験では降水量特よび相対湿度は, いずれも光沢低下を促進することが認められている が， $\mathrm{Muck}^{7)}$ が長油アルキド塗料を使用してフロリダと 西ドイッで一連の暴露実験を括こない，統計的に検討し た結果では降水量は大きいほど光沢低下率は大きくなる が，相対湿度は大きいほど逆に光沢低下率を減少させる という。これらの結果を考慮して, 沖繩就よび淡路島で

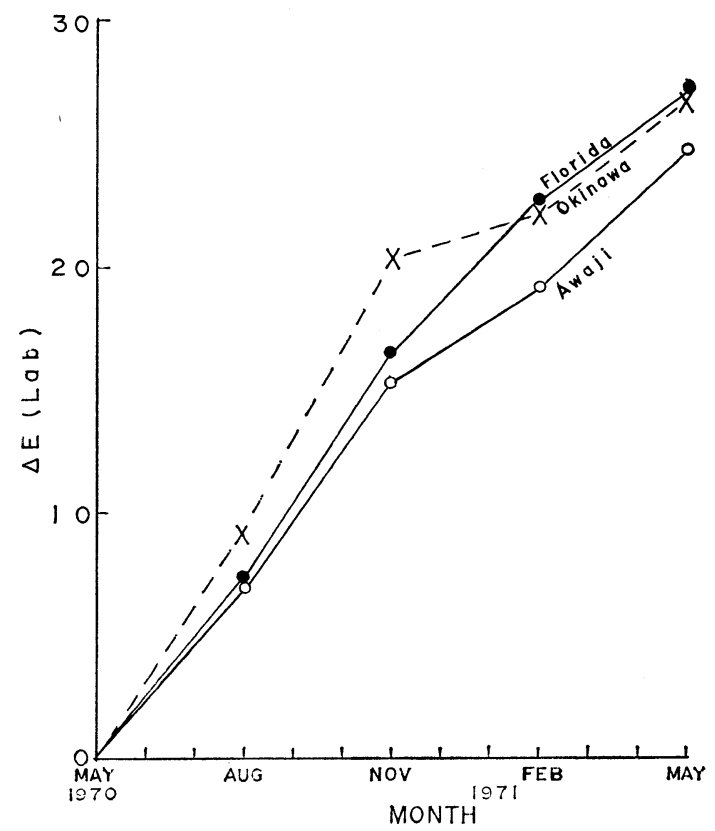

Fig. 11. Color relention of tint shade

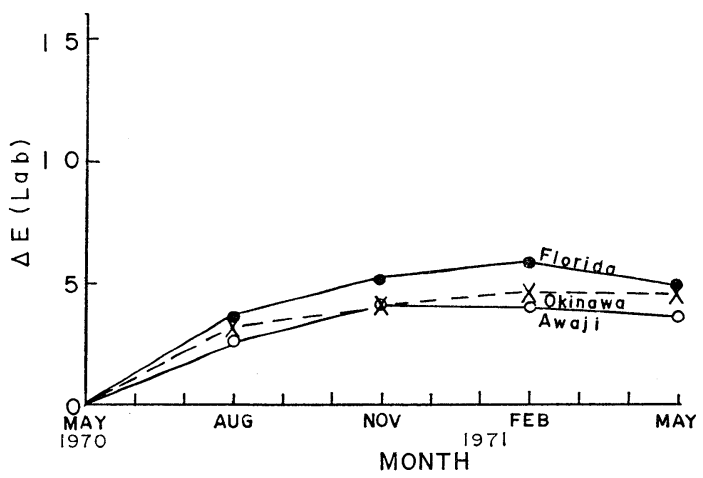

Fig. 12. Color retention of full shade after polishing

の光沢低下がフロリダに比して大きい原因として一応降 水量特よび日照時間の差が挙げられるが，海塩粒子や大 気污染など明らかでない諸因子の影響るありうるので即 断はできない。

図-9〜-11 に見られるように塗面をポリッシュしない 場合の変退色は，原色系では沖繩でとくに著しく，中 色, 淡色系では沖繩とフロリダとでは同程度で, 淡路島 ではこれらに比し約 $80 \%$ 程度であった。

ところが塗面をポリッシュした場合には，図-12, -13 に示したように変色度はフロリダ, 沖繩, 淡路島の順と なり，沖繩特よび淡路島での年間の暴露効果はそれぞれ フロリダの約 $80 \%$ 执よび約 $60 \%$ 程度となっている。 


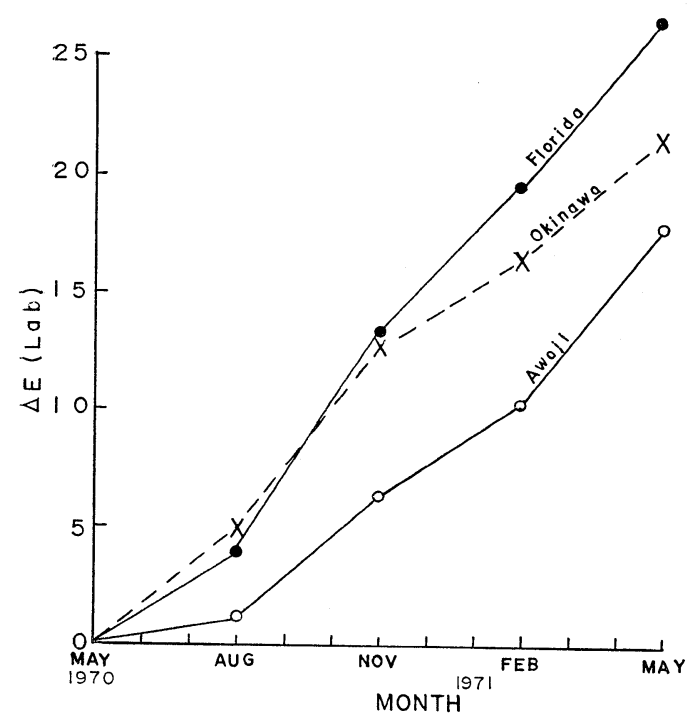

Fig. 13. Color retention of middle shade after polishing

これは期間中の日射量にほぼ比例している。

塗面をポリッシュしない場合の变色は赤顔料の退色か らくる変色と塗面の曇り, 寸なわち光沢の低下による変 色が重なって測定されるので, 後者の効果がより大きい 沖繩および淡路島での変色が大きな值を示す結果になっ ている。とくに濃色では顔料の退色は少ないので表面の 曇りが色差に大きく影響し, その効果が著しかった沖繩 での変色度がフロリダでのそれを越える值になったこと
がわかる。

つぎに図-9〜-11，-13 の変色度の曲線を見ると，沖 繩および淡路島では季節要因の効果が現れ，冬季には変 色度合が低下することが羿められるが，フロリダでは年 間を通じてほぼ直線的に変色していることがわかる。

（1973 年度色材研究発表会にて発表）

\section{参考文献}

1) W.E. Laesch : Off. Dig., 36, 686 (1964)

2）鈴木森夫, 野口 健 : 色材, 41, 534 (1968)

3）栄 幸雄 : 色材, 46, 121 (1973)

4）山崎正八郎, 横井康夫 : 色材, 46, 579 (1973)

5) M.P. Morse : Off. Dig., 36, 695 (1964)

6) H. Muck, R. Amberg, R. Epple : Farbe Lack, 72, 866 (1966)

7) H. Muck, R. Amberg, R. Epple : Farbe Lack, 74, 669 (1968)

8) H. J. Freier : Farbe Lack, 73, 1127 (1967)

9）大谷信吉, 伊丹慶輔, 牧島 博, 高瀬勝次, 瓜谷 詔夫：防蝕技術, 16，475（1967）

10）牧島 博, 高瀬勝次 : 色材, 38, 135 (1965)

11) JWTC =ュース, No. 1 (1972) No. 10 (1973)

12) A.E. Jacobsen : P. V.P., 55 [2], 29 (1965)

13) 松田種光, 栗原福次: 高分子化学, 22, 429 (1965)

14) W.Elser, W. Funke : Deut. Farben-Z., 22, 91 (1968)

15) E. Hoffmann, A. Saracz : JOCCA, 52, 1130 (1969)

16) E. Hoffmann: J. Paint Tech., 43 [563], 97 (1971)

色 材 協 会 誌 Vol. 47, No. 9 (予告)

総説

高分子の吸着と顔料の分散安定性 （1 …….....................

報文

被塗物上塗膜への溶液拡散現象の研究（第 1 報）……

顔料分散の溶解性パラメーターによる若干の評価——分散性パラメーターの決定—

塗料の “はじき” 現象に関する研究 (第 4 報) 顔料の種類と塗料の “はじき” 発生傾

向との関連性

テーマ資料（塗料と塗膜の試験方法）

関西ペイント(株) 佐 藤 忠 明

塗料及び塗膜の電気的試験方法

作業性と塗膜形成過程の試験法

日本ペイント(株) 大 薮 権 昭

塗膜物性の試験法....

促進耐候試験方法

職業訓練大学 吉 田 豊 彦

職業訓練大学 植 木 憲 二 スガ試験機(株) 須 賀 䓪 